\title{
WIERNY LITURGII \\ Laudacja podczas odznaczenia \\ o. dra Franciszka Małaczyńskiego OSB \\ medalem pamiątkowym Polskiego Tow. Teol. w Krakowie, dnia 18 || 1997 r.
}

O. dr Franciszek Małaczyński z zakonu mnichów św. Benedykta - to ks. Stanisław Małaczyński, kapłan archidiecezji lwowskiej obrządku łacińskiego.

Urodzony w 1920 r. we Lwowie. Wychowywał się w środowisku lwowskim tętniącym kulturą polską ale również będącym splotem wątków różnych kultur Wschodu. Niewątpliwie pozostawiło ono znamienny rys nie tylko $\mathrm{w}$ osobowości lecz również działalności o. Franciszka.

Studia teologiczne ukończył we Lwowie. 6 czerwca 1943 r. w kościele Metropolitalnego Seminarium Duchownego we Lwowie został wyświęcony przez biskupa Eugeniusza Baziaka - jako jeden z dziesięciu absolwentów. Tak więc został kapłanem lwowskim a należąc do tejże archidiecezji skierowanym do pracy duszpasterskiej jako wikariusz najpierw do Glinian a potem do Tarnopola. Ponad dwa lata pracował w tarnopolskiej parafii w najtrudniejszym czasie okupacji. Rok 1946 kończył pracę młodego księdza n terenie ziemi lwowskiej. Repatriacja prowadziła w kierunku Ziem Odzyskanych. Krótko pracował w archidiecezji wrocławskiej. We wrześniu 1946 r. został zaproszony do pracy w Laskach k. Warszawy a stamtąd do Żułowa w ziemi lubelskiej.

Opatrzność Boża pokierowała drogami ks. Stanisława jednak w kierunku Tyńca. W zaciszu opactwa tynieckiego miał swoje siły poświęcić realizacji życiowej zasady „Ora et labora”. Po wstąpieniu do zakonu w 1950 r. i złożeniu ślubów przyjął imię Franciszek.

Studia specjalistyczne odbył na Wydziale Teologicznym Uniwersytetu Warszawskiego kończąc je licencjatem teologii oraz w Rzymie w Instytucie Liturgicznym uzyskując doktorat teologii w zakresie liturgiki.

Nie miejsce na charakterystykę życia o. Franciszka i jego działalności w zakonie. Chciałbym krótko wykazać związki o. Franciszka Małaczyńskiego z Polskim Towarzystwem Teologicznym a szczególnie $\mathrm{z}$ czasopismem Ruch Biblijny i Liturgiczny.

Dobre przygotowanie liturgiczne, jeszcze zdobyte we Lwowie, w którym liturgiści ks. Jougan i ks. Cszesznak, zostawili swój znak 
a ponadto środowisko różnych wyznań kierowało już młodego Księdza ku liturgii i jej problemów.

Kiedy z zespołu redakcyjnego RBL odszedł o. Jan WieruszKowalski OSB, będący w nim od założenia pisma, w 1956 r. to miejsce zajął o. Franciszek Małaczyński. Pozostał w nim do dnia dzisiejszego. Podjął odpowiedzialność za dział związany z liturgią. Na łamach tego pisma ogłosił 47 artykułów, 19 recenzji oraz 6 sprawozdań. Jego publikacje objęły różną tematykę: z historii liturgii, teologii liturgii, odrodzenia liturgii, norm liturgicznych, wychowania liturgicznego oraz liturgii sakramentów. Najwięcej miejsca poświęcił księgom liturgicznym przeżywającym swoje odrodzenie i żywe przystosowanie do życia liturgicznego. Podjął się również przekładu tekstów dekretów Stolicy Apostolskiej i opublikował je na łamach pisma. Opublikowane artykuły cechuje wielka staranność i dokładność, dociekliwość i nowoczesność w formułowaniu wniosków oraz ogromny zapał w odnawianiu form życia liturgicznego.

Nie należy pomijać wygłoszonych szeregu referatów o tematyce liturgicznej na posiedzeniach sekcji PTT.

W 1966 r. podjął kierownictwo Archidiecezjalnego Studium Liturgicznego w Krakowie, mającego przygotować kapłanów do wprowadzenia w życie parafialne odnowy liturgicznej. A kiedy przerodziło się ono w Instytut Liturgiczny podjął w nim wykłady i prowadził je przez 10 lat. Wykładał liturgikę w kilki seminariach duchownych w Krakowie (Śląskim Wyższym Seminarium Duchownym, Wyższym Seminarium Duchownym OO. Paulinów na Skałce oraz Instytucie Teologicznym XX. Misjonarzy).

Od 1957 r. pełnił funkcję sekretarza Komisji Episkopatu Polski do spraw Liturgii i Duszpasterstwa Liturgicznego. Tu włożył ogromny wkład w przygotowanie polskiego mszału i polskiego brewiarza. Zwłaszcza ten ostatni kosztował wiele wysiłku o. Małaczyńskiego.

Wchodził również w skład zespołu tynieckiego przygotowującego polski przekład Pisma świętego zwany Biblią Tysiąclecia.

Wdzięczni za wkład w działalność Polskiego Towarzystwa Teologicznego w Krakowie a szczególnie za prace w zespole redakcyjnym Ruchu Biblijnego i Liturgicznego, chcemy przyznać o. drowi Franciszkowi Stanisławowi Małaczyńskiemu OSB medal jako wyraz wdzięczności i uznania, na który w pełni zasługuje. 